\title{
Energy saving methods as a necessary component of architectural improvement of uniform housing development
}

\author{
Tatiana Vavilova, ${ }^{1, *}$, and Irina Zhdanova ${ }^{1}$ \\ ${ }^{1}$ Samara State Technical University, Institute of Architecture and Civil Engineering, \\ 194, Molodogvardeyskaya St., 443001, Samara, Russia
}

\begin{abstract}
The aim of the study was to create a complete picture of the system of architectural energy-saving methods that can be used in the modernization of residential buildings erected in the era of the industrial uniform construction. The following tasks were solved: to clarify the special features of the main stages in the development of uniform construction in Russia; to determine the fundamental differences of the buildings constructed at different times in terms of energy efficiency; to develop proposals for energy-efficient architectural modernization of uniform constructions. Field surveys of a number of housing estates and neighborhoods, analysis of theoretical sources and advanced foreign experience in the reconstruction of rental and affordable housing allowed us to systematize technologies of energy-saving renovation of buildings and visualize their implementation for buildings of Series 90. Examples are given.
\end{abstract}

\section{Introduction}

The recognition of the fact that construction and operation of real estate are processes affecting the environment has led to a revision of strategies to address the housing problem. Early in the $21^{\text {st }}$ century, more and more attention is paid to the modernization of the existing housing stock. In many countries, it needs to be adapted to new energy standards. The largest amounts of mass housing were built in the USSR. More than 375 million $\mathrm{m}^{2}$ of housing in urban area and not less than 165 million $\mathrm{m}^{2}$ in the rural area were built during the period from 1971 to 1975.

\section{Materials and Methods}

\subsection{Stages of development of uniform construction in Russia}

At present, according to the Russian Ministry of Construction, more than $50 \%$ of the housing stock, which is home to about 45 million people, is in need of total renovation. The

* Corresponding author: vatatyan63@yandex.ru 
majority of objects are buildings of standard series dating back from the 1950s to early 1980s that do not comply with modern energy-saving standards: in comparison with European countries heating one unit of residential area consumes 2-3 times more energy in Russia [1].

We can distinguish two main periods in the development of uniform industrial housing construction in the USSR. One of them started in the second half of the 1950s, when the Soviet Union switched to the construction of standard housing with factory-built prefabricated structures. By 1965, it was planned to increase the annual volume of largepanel construction up to 25 million $\mathrm{m}^{2}$. The first houses built according to standard designs were mainly five-storied. They are characterized by a narrow bulk (10-12 $\mathrm{m})$ and pitched roofs. In the early $1960 \mathrm{~s}$, the series rose to 9-storied constructions, and later to singlesectioned 12-14-storied residential buildings. During these years, the width of the building bulk was determined by the decreased size of the main and ancillary rooms. The main type of summer premises included balconies. In the mid-1960s there appeared series with the increased area of residential and ancillary rooms, which were equipped with separate bathrooms and built-in wardrobes. In some series enclosed balconies were used that enhanced energy efficiency [2]. Linked sections, as a rule, had a minimum of 4 apartments on a floor. This made it possible to optimize the area of building-level communication spaces and led to broadening of the bulk [3].

During the second period (1970-1980s) in the Soviet Union, there was an increase in the number of options for house planning decisions on the basis of a unified product catalogue. Along with the five-storied buildings, series of 9-, 12-, 16-storey large-panel housing with a flat roof began to be built. Apartments became larger in size, the number of ancillary rooms increased, bay windows and combinations of balconies and enclosed balconies appeared. These homes are characterized by a wider bulk compared to the houses of the previous period. An important step on the way of thermal energy savings was the introduction of manual or automatic in-apartment regulators on radiators [3].

Analysis of the Soviet period practice of designing and building uniform constructions showed that the housing belonging to different periods did not only have different thermal performance of building envelopes, but also different framing schemes and geometric parameters of the footage [4]. However, existing technologies that took into account regional peculiarities, did not provide lower energy consumption. Facade and roof systems of these buildings, fillings of the window and door openings do not meet modern requirements of energy saving and require replacement. The fact that at the beginning of the $21^{\text {st }}$ century quality standards and housing needs of the population changed as well plays an important role. Therefore, the principle of increasing energy efficiency of residential premises during reconstruction is the necessary condition for improvement of their consumer properties and extending their life cycle $[5,6]$.

\subsection{Experience of improving energy efficiency of uniform housing}

\subsubsection{European countries}

A wide range of techniques and methods of residential buildings renovation is used in the countries of Northern and Central Europe. According to European Commission Directives 2002/91/ EC and 2010/31/ EU on energy efficiency of buildings, it is recommended to ensure compliance with the minimum requirements for energy efficiency as a result of total renovation or modernization of the existing facilities. The most important condition for the development of reconstructive actions is taking into account national, regional and local peculiarities, especially climatic factors. In some countries, the economic incentives are used to increase the number of buildings with almost zero energy consumption. 
The UK [7-12], Germany [13-15], Switzerland [16], Sweden [17] and other European countries, including countries of the former socialist camp, pay particular attention to the scientific basis of increasing energy efficiency properties of buildings created in the era of uniform industrial construction. For example, K. Kuusk and T. Kalamees estimated that in Estonia about $90 \%$ of apartment buildings were constructed before 1990 and need to be modernized $[18,19]$. Improving the quality of mass housing of the Soviet era is studied by scientists of Hungary [20], Latvia [21], Lithuania [22] (fig. 1), Poland [23], Slovakia [24].
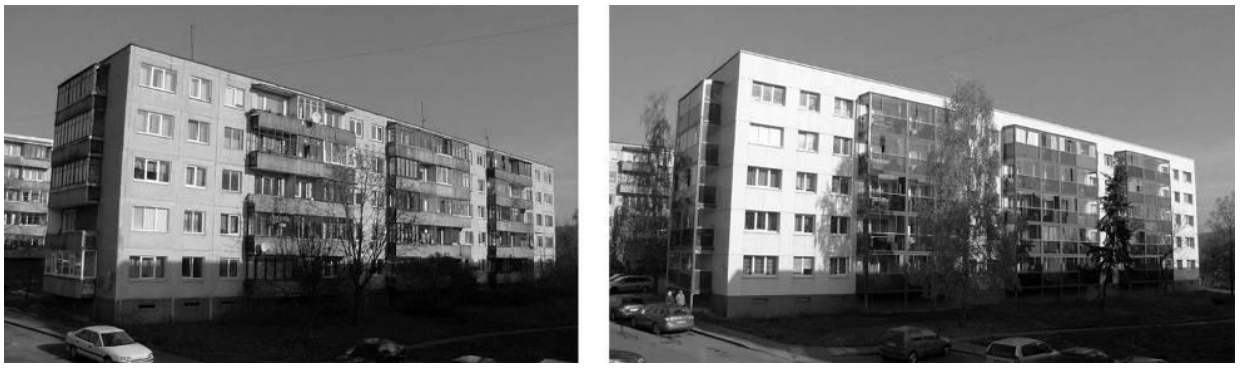

Fig. 1. Example of Modernization of the Soviet Period Building in Vilnius (Before and After).

Germany was one of the leaders in the process of modernization of large-panel residential buildings. In this country, in the early 1990s, the authorities found it necessary to implement measures for housing modernization and improvement of its energy efficiency, in accordance with modern requirements; depending on the year of construction of buildings, technological schemes providing improved operational reliability of the housing purposefully began to be used during the reconstruction. On the territory of East Germany, about $70 \%$ of the buildings had undergone reconstruction by 2010 . In Berlin, about $60 \%$ of panel houses underwent complete redesign, and 25\% underwent partial redesign. Energysaving measures included heat insulation of the roof and technical floor, facade insulation, replacement of windows, insulation of the basement flooring, replacement of heating and hot water systems and replacement of the ventilation system. It was estimated that energy saving consumes about $25 \%$ of capital investments [25]. Germany's leadership was confirmed in 2007 when it began to consistently introduce energy certification of buildings. By 2009, the technique spread to all types of housing, regardless of the time of construction. [26] A comprehensive approach, taking into account technical, economic and social factors, ultimately led to an increase in the market value of the secondary housing [27].

\subsubsection{Russian Federation}

In the beginning of the $21^{\text {st }}$ century problems of energy-efficient modernization of residential development in the Russian Federation get special attention. However, we should remember that in the late 1960s in the USSR, the first attempts of scientific systematization of architectural (S. B. Baratz, 1967) and engineering (M. S. Shumilov 1967, V. K. Sokolov, 1969) methods of reconstruction and replanning of housing were taken. At the end of the 1980s the architects (Y. I. Bakhmutov, 1987, V. N. Kutukov, 1988, N. A. Chilingaryan, 1997, T. A. Rak, 2000) and builders (G. A. Sargsyan, 1990 , K. A. Schreiber, 1991, Y. V. Kononovich, 1992, E. P. Matveev, 2000, V. F. Kasyanov, 2003) showed renewed interest in the subject. At the beginning of the 2000 s several scientists introduced thesis research devoted to the justification of the economic feasibility of reconstruction (I. V. Akulenkova, 2004, S. S. Bachurina, 2005, T. Y. Ovsyannikova, 2005, O. B. Khokhlov, 2006, I. L, Slepuhina, 2009 A. A. Kasatkin, 2011, E. M. Korshunova, 2015, Y. I. Faizrakhmanova, 2015). In these years, in some architectural (S. N. Smirnova, 
2009, I. V, Zhdanova, 2013), as well as many technical (A. A. Shevchenko, 2004, A. M. Beregovoy, 2005, E. E. Semenova, 2006 , L. B. Director, 2008, M. I. Nizovtsev, 2009, A. S. Bagin, 2010, A. A. Benuzh, 2013, A. V. Maltsev, 2014, E. V. Martynova, 2014, P. A. Zhuravlev, 2015, L. A. Oparina, 2016, S. Z. Usmonov, 2016) and economic (T. V. Spiridonov, 2005, A. A. Bruma, 2010, K. P.Grabovy, 2010, D. V. Mishin, 2012, S. S. Shikhaliyev, 2012, E. I. Pavlov, 2013, V. G. Selishchev 2014) thesis research there appears a steady shift towards energy efficient building technologies and housing reconstruction.

However, despite the solid scientific basis, according to Russian Federal State Statistics Service data for 2015, in the Russian Federation, the share of housing that had been commissioned after the reconstruction was only $0.6 \%$. St. Petersburg (1.9\%), as well as a number of other areas (Sverdlovsk (1.8\%), Rostov (2.8\%), Lipetsk $(5.9 \%)$ and Ivanovo $(10.7 \%))$ stand out of the others. Figure 2 shows some recent examples of modernization of uniform premises of the Soviet period.

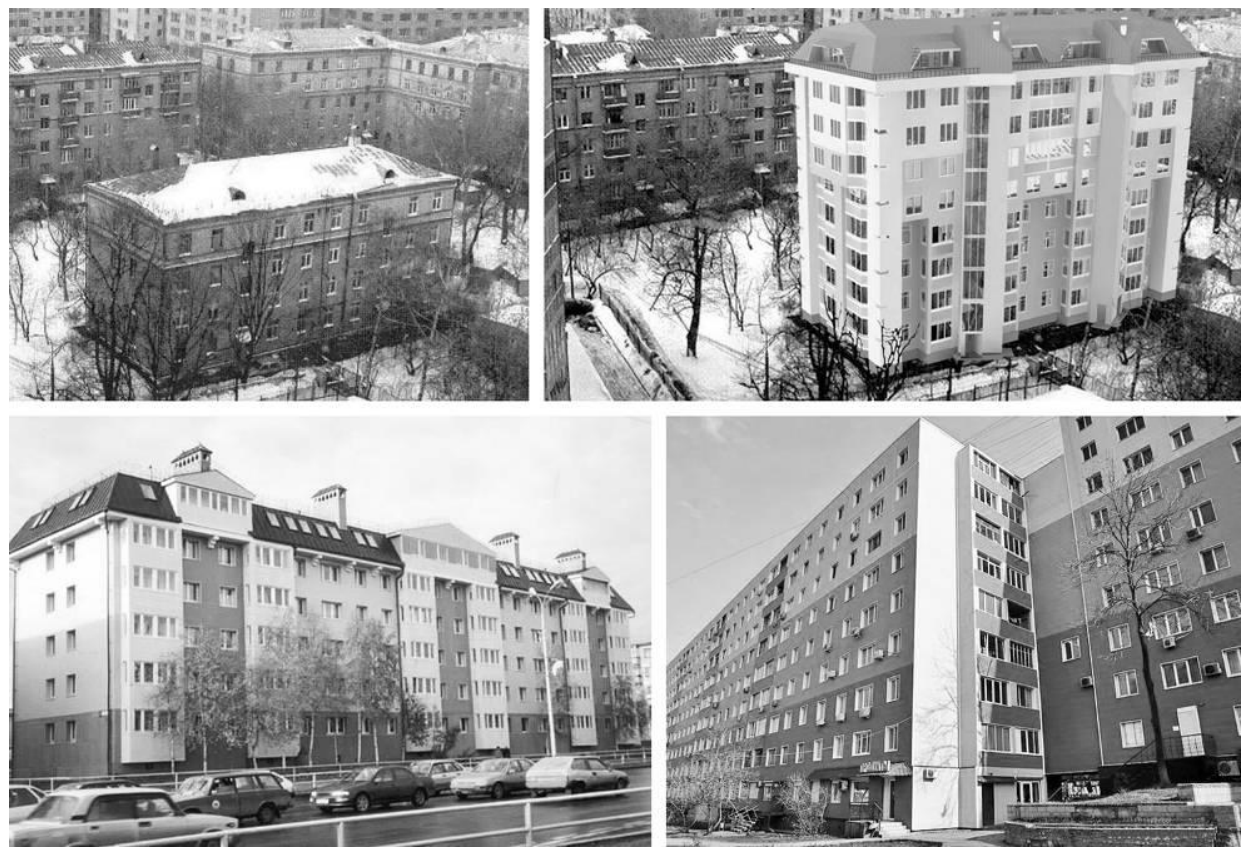

Fig. 2. Example of Reconstruction of Uniform Premises in Moscow (Before and After), Surgut and Vladivostok.

Currently, in the Russian Federation there is a system of State standards for designing of buildings taking into account environmental requirements, as well as indicators of their energy efficiency. In 2011, in accordance with a number of federal laws the rules for determining the classes of energy efficiency of apartment buildings, updated in 2016, began to be implemented. As the State report on the state of energy saving and energy efficiency improvements show, the country's average proportion of all buildings with preliminary energy efficiency class no lower than D type was $15.4 \%$ in 2015 . The requirements for capital construction and renovation of houses were introduced by 2014 only in 27 regions and in Moscow, and by 2015 in 9 other regions of the Russian Federation.

It should be also noted that Russia is gradually acquiring techniques of promotion of advanced international practices. For example, since 2004 the German Society for international cooperation (GIZ) started holding seminars for the graduates of the 
Presidential program of the Russian Federation. The actual result of this cooperation was the project of the complex energy efficient refurbishment of a residential panel house series 137 in St. Petersburg [28].

\subsection{Aims and objectives of the study}

As part of a long-term research work, funded from the federal budget, at the Chair of Architecture of residential and public buildings of the Institute of Architecture and Civil Engineering of Samara State Technical University, we have developed a set of measures to improve consumer properties of a series 90 of residential buildings. In 1970s, industrial construction of this series was mastered in Mordovia, Tatarstan and Moscow region, Novgorod, Volgograd, Vologda, Orenburg, Penza, Rostov-on-Don, Samara (Kuibyshev), Saratov, Smolensk, Ulyanovsk and other cities. At that time, the authors of this series used quite high social standards. The catalogue included more than 180 standard projects of houses and block sections. The nomenclature included block-sections of various configurations: ordinary, face, rotary and angular with internal or external angles of rotation at $135^{\circ}$ and $90^{\circ}$. They also designed hostels for workers and employees, as well as houses of farmstead type with one or two apartments.

The aim of the study is the development of quality estimation system of architectural and spatial solutions of the living environment and identification of modern methods of improving its consumer properties during the reconstruction of uniform housing [29]. A number of subtasks involved systematization of particular criteria for assessing the quality of the living environment, definition of the complex target methods of architectural and planning improvement of uniform premises of $70-80 \mathrm{~s}$ of the $20^{\text {th }}$ century, as well as the development of proposals to improve consumer properties of apartments and houses of 90 series. The area of study was Samara region - a city with a population of about 1 million 200 thousand people, the center of Samara-Togliatti agglomeration.

\section{Results and discussion}

One of the priorities of the study was a set of factors that promote energy efficient qualities of the living environment. The objective of the first stage of work was the mapping of existing residential areas in Samara occupied with houses of the 90 series, and systematization of typical options for incorporating buildings into the urban environment. Field surveys and studies of supporting drawings showed that the predominant part of the neighbourhood area is used inefficiently. There are significant opportunities for increasing construction density. At the second stage we developed project models for creation of additional areas, for modernizing buildings and changing of planning decisions of individual residential premises. At the same time we took into account existing social standards and regional climatic features. In the end, it was proposed to perform modernization based on the residents' voluntary choice of one of the three types of targeted alternative programs: standard reconstruction - for consumers with low incomes, advanced reconstruction - for consumers with an average income and comfort reconstruction - for consumers with high income. Basically, the options for redevelopment of residential cells according to respective models were as follows: "standard" (one of the rooms in the apartment can accommodate two people), "advanced" (each family member has a personal bedroom) and "comfort" (the apartment has one or more non-bedroom spaces for shared use).

Analysis of basic theory as well as of international and Russian practice of uniform housing modernization of industrial era [1-39] allowed us to generalize and systematize the basic techniques that improve energy-efficient features of buildings. This made it possible 
to choose the methods of functional, ergonomic, engineering, technical, environmental and aesthetic improvement as priority methods for reconstruction of residential units and houses. In the study, a strong correlation was observed between the architectural and engineering solutions and their interdependence. As a result, the following integrated technologies to help improve energy efficiency became the basis for the development of a 90 series apartment buildings modernization models:

- Extension of additional sections to the end parts of the building,

- Increase in bulk buildings width and height - adding one or more attic floors (fig. 3), building up recessed balconies or bay windows to the residential premises, increasing the size of the residential part of the building due to non-heated premises (fig. 4),
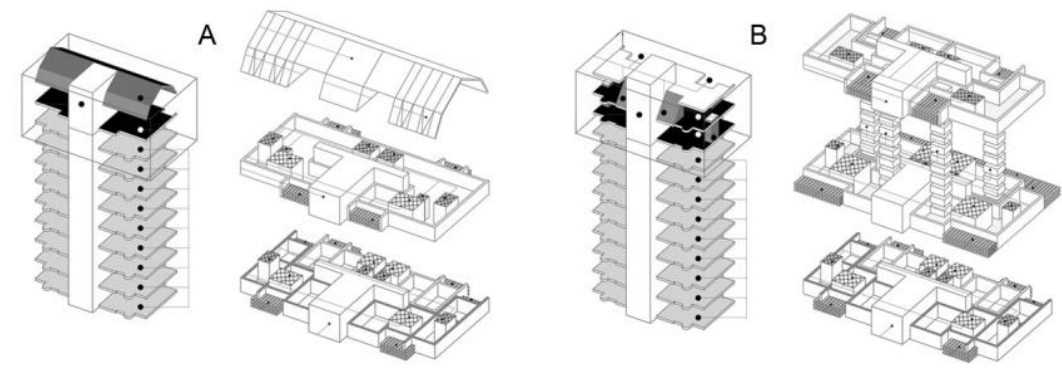

Fig. 3. Options for Building-up Residential Sections.

- Thermal insulation of the building envelope - exterior walls, basement floors, roofs due to landscaping, renovating designs of door and window openings, glazing recessed balconies and balconies, etc.,

- Modernization of ventilation systems - the replacement of passive systems for forced system with heat recovery of exhaust air,

- Horizontal heating systems, with the installation of a programmable control system interlocked with apartment ventilation control system,

- Equipment of buildings with metering devices for hot and cold water and metering devices for the heating system,

- Modernization of heating units with installation of equipment for control of energy consumption, etc.,

- The introduction of alternative energy sources.
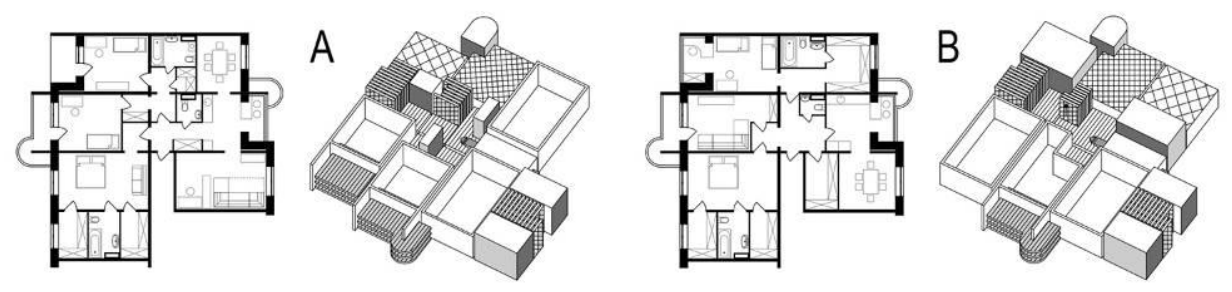

Fig. 4. Options for Redevelopment of Residential Units (A - advanced option, B - comfort option).

\section{Conclusions}

The given study has helped to distinguish two main groups of uniform series houses in terms of energy efficiency. We clarified the fundamental differences between buildings belonging to different stages of development of prefab construction in Russia, according to the number of stories, bulk width, roof characteristics, organizing entrance and non-heated 
areas. The research provides a full picture of the system of interconnected architectural techniques that can be used for energy-efficient modernization of residential environment. Based on 90 series, which became widespread in a number of regions of Russia, we have developed proposals for the modernization of energy-efficient architectural solutions for individual apartments, residential buildings and residential complexes. The results of study suggest a high consumer potential of housing, built in the era of mass prefab construction, and the possibility of its adapting to the changing socio-economic and environmental conditions.

\section{References}

1. V. M. Tsygankov, Reality: Economics, Management, 2, 45-48 (2015)

2. A. Y. Konyashkina, News of Landscape Architecture, 4, 40-47 (2014)

3. I. V. Zhdanova, Internet-Vestnik VolgGASU, 1 (25), 5 (2013)

4. A. N. Youzefovitch, PNRPU Bulletin. Applied Ecology. Urban Development, 4, 107$121(2011)$

5. E. Eikfoff, L.G. Hodov, World and National Economy, 3 (6), 51-64 (2008)

6. T. V. Stebenyaeva, S.M. Ostrovsky, Problems of Modern Science, 3, 213-224 (2012)

7. M. Bell, R. Lowe, ENERG BUILDINGS, 32, Is. 3, 267-280 (2000)

8. R. Howes, Advances in Building Technology, I, 383-390 (2002)

9. D. Gibbs, K. O’Neill, GEOFORUM, 59, 133-141 (2015)

10. M. M. Valença, HABITAT INT, 49, 107-114 (2015)

11. S. L. Walker, D. Lowery, K. Theobald, Energy Research \& Social Science, 2, 102-114 (2014)

12. Ph. Davies, M. Osmani, BUILD ENVIRON, 46, Is. 8, 1691-1698 (2011)

13. H. Harter, V. Weiler, U. Eicker, BUILD ENVIRON, 112, 166-176 (2017)

14. A. Radzimski, CITIES, 50, 197-205 (2016)

15. T. Konstantinou, U. Knaack, Procedia Engineering, 21, 666-675 (2011)

16. B. Wehle, Ch. Geyer, A. Müller, Energy Procedia, 78, 895-900 (2015)

17. P. Johansson, P. Femenías, L. Thuvander, P. Wahlgren, Energy Procedia, 96, 170-179 (2016)

18. K. Kuusk, T. Kalamees, Energy Procedia, 78, 985-990 (2015)

19. K. Kuusk, T. Kalamees, Energy Procedia, 96, 628-637 (2016)

20. Z. Balló, Procedia Engineering, 161, 2079-2087 (2016)

21. M. Gentile, Ö. Sjöberg, J HIST GEOGR, 36, Is. 4, 453-465 (2010)

22. M. Staniūnas, M. Medineckienė, E.K. Zavadskas, D. Kalibatas, ARCH CIV MECH ENG, 13, Is. 1, 88-98 (2013)

23. D.-A. Krawczyk, Energy Procedia, 95, 216-222 (2016)

24. V. Földváry, H. Pustayová Bukovianska, D. Petráš, Energy Procedia, 78, 2184-2189 (2015)

25. D. V. Kovalev, V.G. Chudinova, Bulletin of SUSU. Series Construction Engineering and Architecture, 1, 4-8 (2013)

26. L.R. Ibrasheva, M.M. Chekurova, Bulletin of the Technological University, 16, Is. 3, 281-287 (2013) 
27. V. Belov, B. Shvarc, Energy Efficient Refurbishment of Typical Residential Buildings: the German Experience for the Russian Regions: a Collection of Analytical Materials on International Cooperation of the German Society Seminar (GIZ) for Associations of Graduates of the Presidential Program of the Russian Federation (GIZ, GmbH, 2013)

28. V. Pukhkal, Procedia Engineering, 117, 616-623 (2015)

29. T. Y. Vavilova, N. D. Potienko, I. V. Zhdanova, Procedia Engineering, 153, 938-943 (2016)

30. S. G. Abramyan, Scientific Open Access Journal Naukovedenie, 8, Is. 1 (32), 38 (2016)

31. H. A. Benai, I. G. Baluba, T. V. Radionov, Modern Industrial and Civil Construction, 1, 5-12 (2016)

32. E. P. Borisova, E. A. Akhmedova, Urban Construction and Architecture, 1 (5), 6-10 (2012)

33. V. P. Generalov, E. M. Generalova, Urban Construction and Architecture, 4 (21), 23$29(2015)$

34. L. V. Glebushkina, L.V. Peretolchina, Systems. Methods. Technologies, 3, 182-191, (2016)

35. V. V. Gurov, Vestnik MGSU, 4-5, 67-70 (2010)

36. I. Y. Zilberova, K. S. Petrov, Engineering Journal of Don, 4-1 (22), 148 (2012)

37. S. N. Larin, Economic Analysis: Theory and Practice, 17 (320), 33-39 (2013)

38. E. V. Martynova, S. G. Sheina, Procedia Engineering, 150, 1983-1988 (2016)

39. S. N. Ovsyannikov, A. N. Ovsyannikov, News of Tomsk Institute of Architecture and Civil Engineering, 2, 105-112 (2010) 